Sergey Bosakov, DSc in Engineering Science, Professor, Chief Researcher, Institute BeINIIS RUE; Professor, Department of Mathematical Methods in Construction, Belarusian National Technical University (Minsk, Belarus)

Oksana Kozunova, PhD in Engineering Science, Associate Professor, Department of Architecture and Construction; Head of Design Department, Belarusian State University of Transport (Gomel, Belarus)

\title{
DEVELOPMENT OF THE THEORY OF COMPUTATION OF PIVOTALLY-CONNECTED BEAMS ON AN ELASTIC FOUNDATION TAKING INTO ACCOUNT THEIR PHYSICAL NONLINEARITY
}

(C) РУП “Институт БелНИИС", 2019

Institute BeINIIS RUE, 2019

\section{ABSTRACT}

This work presents a brief review of the literature on the theory and technique of computation of pivotally-connected structures on a linearly-elastic foundation. The authors refer to the works of B.G.Korenev, G.Ya.Popov, I.A.Simvulidi, R.V.Serebryany and A.G.Yuryev, in which investigations for calculating the pivotally-connected beams and slabs on an elastic foundation are performed using different approaches.

From the analysis of the scientific and normative literature on the subject under consideration, a conclusion can be made that there is no common approach to solution of this problem, which would hold for any pivotally connected structures being in contact with any elastic foundation model under the action of an arbitrary external load.

Besides, when designing the load carrying members of pavements of motor roads of various purposes in the Republic of Belarus, a number of branch-specific normative documents, where the pavements with the load carrying member and interconnection of members over the track length are considered separately in unconnected setting, is used. 
In this work, a universal approach for computation of pivotally-connected beams on an elastic foundation in the linear setting and taking into account the physical nonlinearity of the beam material is proposed. This approach is based on a mixed method of structural mechanics and implemented in different foundations taking into account the Zhemochkin's relations for the functions of influences of an elastic medium.

The following hypotheses and assumptions of the linear theory of elasticity and structural mechanics are taken into consideration: only normal stresses act at the contact of the beam with the foundation; for beams the hypotheses of the flexural theory; the pivot joints are cylindrical and the distribution of the contact stresses over the beam width is uniform.

The physical nonlinearity of the beam material is taken into consideration through the variable rigidity of the Zhemochkin's areas. Namely: after determining the forces in the Zhemochkin's bonds at the contact of every beam with an elastic foundation as a result of the linear computation, the values of bending moments in each section of every beam are determined by the structural mechanics methods. From the calculated values of the moments, the tangential rigidity for each Zhemochkin's area on the beam is determined using the formula of the "moment-curvature" dependence for the beam sections are determines as hyperbolic tangent.

In the results of nonlinear computation, the stress-strain behaviour of the system of pivotally-connected beams on an elastic foundation is investigated as it was made earlier in the linear setting: distribution of contact stresses under the beams, internal forces in the beams and pivot joints as well as elastic foundation settlements.

The proposed approach is implemented numerically with the use of the Mathematica 10.4 mathematical package. The computation example for three pivotally-connected beams on the Winkler foundation taking into account their physical nonlinearity.

Keywords: pivotally-connected beams, mixed method, Zhemochkin's bonds, Winkler foundation, nonlinear computation, "moment curvature" dependence, contact tension, elastic foundation settlements.

For citation: Bosakov S., Kozunova O. Development of the theory of computation of pivotally-connected beams on an elastic foundation 
taking into account their physical nonlinearity. Contemporary Issues of Concrete and Reinforced Concrete: Collected Research Papers. Minsk. Institute BelNIIS. Vol. 11. 2019. pp. 11-24. https://doi. org/10.35579/2076-6033-2019-11-01

Босаков Сергей Викторович, А-р техн. наук, профессор, главный научный сотрудник РУП "Институт БелНИИС"; профессор, кафеАра "Математические методы в строительстве", Белорусский национальный технический университет (г. Минск, Беларусь)

Козунова Оксана Васильевна, канА. техн. наук, Аоцент кафедры “Архитектура и строительство", начальник проектно-конструкторского отАела, УО «Белорусский госуАарственный университет транспортам (г. Гомель, Беларусь)

\section{РАЗВИТИЕ ТЕОРИИ РАСЧЕТА ШАРНИРНО- СОЕАИНЕННЫХ БАЛОК НА УПРУГОМ ОСНОВАНИИ С УЧЕТОМ ИХ ФИЗИЧЕСКОЙ НЕАИНЕЙНОСТИ}

\section{АННОТАЦИЯ}

В работе приводится краткий обзор литературы по теории и методикам расчета шарнирно-соединенных конструкций на линейно-упругом основании. Авторы ссылаются на работы Б. Г. Коренева, Г. Я. Попова, И. А. Симвулиди, Р. В. Серебряного, А. Г. Юрьева, в которых различными подходами проведены исследования по расчету шарнирно-соединенных балок и плит на упругом основании.

Из анализа научной и нормативной литературы по рассматриваемой тематике можно сделать вывод об отсутствии общего подхода к решению этой проблемы, справедливого для любых шарнирно-соединенных конструкций, контактирующих с любой моделью упругого основания под действием произвольной внешней нагрузки.

Кроме того, при проектировании несущих элементов дорожных покрытий автомобильных дорог различного назначения в Республике Беларусь используется ряд отраслевых нормативных документов, в которых дорожная одежда с несущим әлементом $u$ 
соединение элементов между собой по длине трассы рассматриваются отдельно, в несвязной постановке.

В данной работе предлагается универсальный подход для расчета шарнирно-соединенных балок на упругом основании в линейной постановке и с учетом физической нелинейности материала балок. Этот подход основан на смешанном методе строительной механики и реализуется в разных основаниях с учетом соотношений Жемочкина для функций влияний упругой среды.

В расчет принимаются следующие гипотезы и допущения линейной теории упругости и строительной механики: на контакте балки с основанием действуют только нормальные напряжения, для балок справедливы гипотезы теории изгиба, шарниры между балками являются цилиндрическими, распределение контактных напряжений по ширине балок-равномерное.

Физическая нелинейность материала балок в предлагаемом расчете учитывается через переменную жесткость участков Жемочкина. А именно: после определения усилий в связях Жемочкина на контакте каждой балки с упругим основанием в результате линейного расчета, методами строительной механики определяются величины изгибающих моментов в каждом сечении каждой балки. По вычисленным значениям моментов определяется касательная жесткость для каждого участка Жемочкина на балках по формуле зависимости «момент-кривизна» для сечений балки в виде гиперболического тангенса.

В результатах нелинейного расчета, как и ранее в линейной постановке, исследуется напряженно-деформированное состояние системы из шарнирно-соединенных балок на упругом основании: распределение контактных напряжений под балками, внутренние усилия в балках и шарнирных соединениях, а также осадки упругого основания.

Численная реализация предлагаемого подхода выполнена с использованием математического пакета Mathematica 10.4. Приведен пример расчета для трех шарнирно-соединенных балок на основании Винклера с учетом их физической нелинейноcmu. 
Ключевые слова: шарнирно-соединенные балки, смешанный метод, связи Жемочкина, основание Винклера, нелинейный расчет, зависимость «момент-кривизна», контактные напряжения, осадки упругого основания.

Для цитирования: Босаков, С. В. Развитие теории расчета шарнирно-соединенных балок на упругом основании с учетом их физической нелинейности / С. В. Босаков, О.В.Козунова // Проблемы современного бетона и железобетона : сб. науч. тр. / Ин-т БелНИИС; редкол.: О. Н. Лешкевич [и др.]. - Минск, 2019. Вып. 11. -C. 11-24. https://doi.org/10.35579/2076-6033-2019-11-01

\section{INTRODUCTION}

Vitality of the problem. Literature Review. The investigations for computation of pivotally-connected linearly elastic beams and slabs on an elastic foundation were performed in the USSR by B.G.Korenev [1], who proposed the use of angular deformation to describe a jump in angular motion to the left and right from the intermediate pivot joint between neighbouring beams. G.Ya. Popov [2] used a complex mathematical apparatus to obtain the accurate solution for the contact problem of bending of pivotallyconnected beams on an elastic semi-plane. N.I.Simvulidi [3] proposed the method of computation of composite beams on an elastic foundation; however it does not take into account the mutual influence of the beams. R.V.Serebryany [4] gave a solution to a spatial problem of bending of pivotally-connected rectangular slabs on the elastic half-space and compiled the tables to facilitate the engineering computations. A.G.Yuryev [5] used a L.P.Vinokurov's integral method to solve this problem.

From the analysis of the scientific literature on the computation of pivotally-connected structures on an elastic foundation, a conclusion can be made that there is no common approach to solving this problem, which would fold for pivotally-connected beams and slabs that are secured on any elastic foundation model under the action of an arbitrary external load. 
Further, the authors propose the universal approach to computation of pivotally-connected beams taking into account their physical nonlinearity on an elastic foundation based on a mixed method of structural mechanics [6] and B.N.Zhemochkin [7]. This approach holds for beams of various lengths and rigidities, on any model of an elastic foundation and action of arbitrary external vertical load.

Setting the problem and algorithm of the linear computation Let us consider a system of pivotally-connected beams on an elastic foundation under the action of external load (Figure 1). It is required: to determine the distribution of contact stresses under the beams, forces and settlements. We will assume [8] that only normal stresses act at the contact between the beam and the foundation, the hypotheses of the theory of bending hold for the beams and the pivot joints between the beams are cylindrical. The distribution of the contact stresses over the width is uniform.

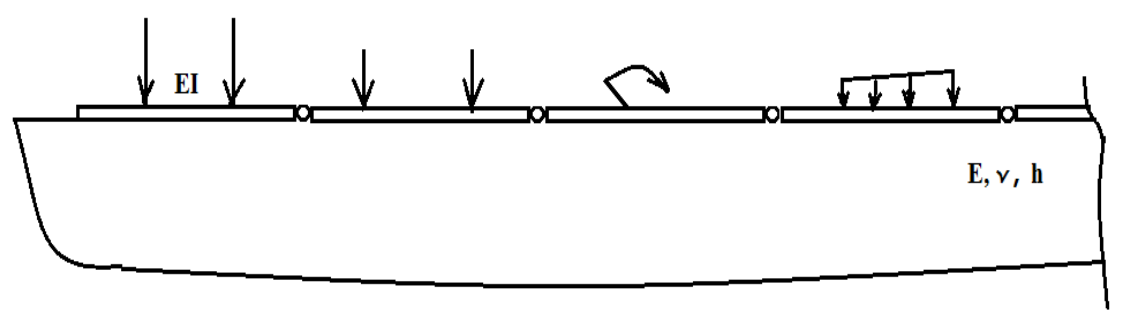

Figure 1. System consisting of pivotally-connected beams on an elastic foundation

We will divide each beam into areas with equal length and put a vertical link, through which the contact of the beam with the elastic foundation is provided, at the centre of each area (Figure 2). The obtained multiply statically indeterminate system will be solved by the mixed method of structural mechanics [6] while assuming the unknown forces $X_{k}$ in the Zhemochkin's bonds at the contact between the beams and the foundation to be linear and angular motions $u_{k}, \varphi_{k}$ of the pinching introduced at the edges of the beams and transverse forces $Q_{k}$ in the split intermediate pivot joints. 


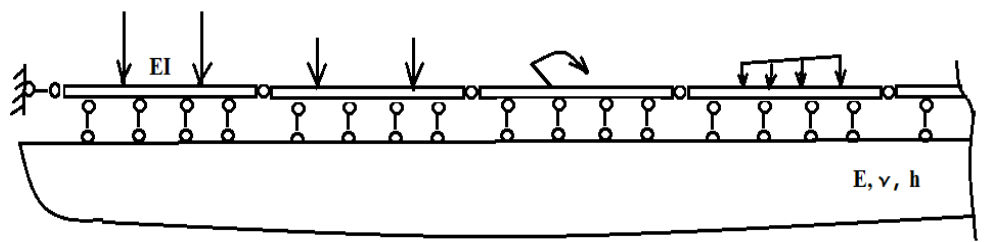

Figure 2. Zhemochkin's bonds at the contact between the beams and the foundation

The basic system of the mixed method is illustrated in Figure 3.

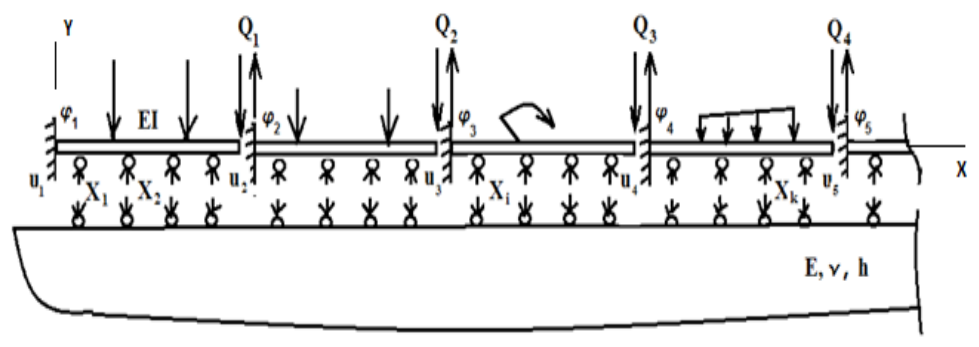

Figure 3. Basic system of the mixed method

System of canonical equations of the mixed method for computation of one beam with the number $i$ appears as follows:

$$
\left\{\begin{array}{l}
\delta_{1,1} X_{1}+\ldots+\delta_{1, m} X_{m}+u_{i}-\varphi_{i} x_{1}-\delta_{1, Q} Q_{i}+\Delta_{1, p}=0 \\
\ldots \\
\delta_{m, 1} X_{1}+\ldots+\delta_{m, m} X_{m}+u_{i}-\varphi_{i} x_{m}-\delta_{m, Q} Q_{i}+\Delta_{m, p}=0 \\
-\sum_{k=1}^{m} X_{k}+Q_{i, 1}+R=0 \\
\sum_{k=1}^{m} X_{k} x_{k}-\ell Q_{i, 1}-M=0 \\
\sum_{k=1}^{m} \delta_{k, Q} X_{k}-\delta_{i, Q} Q_{i}-u_{i}+\ell \varphi+\Delta_{Q, p}+u_{i+1}=0,
\end{array}\right.
$$

where $m$ - is the number of Zhemochkin's areas on a single beam; $u_{i}, \varphi_{i}-$ are unknown linear and angular motions of the introduced pinching on the beam with the number $i$; 
$R, M-$ is the resultant of the external forces and moment of the resultant relatively to the introduced pinching on the beam with the number $i$;

$Q_{i}$ - is the transverse force in the split pivot joint on the right side of the beam with the number $i$;

$X_{k}$ - is the force in the Zhemochkin bond with the number $k$.

The coefficients at the unknown variables of the system of canonical equations of the mixed method (1) appear as follows:

1) for the Winkler foundation

$$
\begin{aligned}
& \delta_{i, k}=\frac{1}{K b}+\frac{\ell^{3}}{3 E} w_{i, k}, \quad i=k ; \\
& \delta_{i, k}=\frac{\ell^{3}}{3 E} w_{i, k}, \quad i \neq k,
\end{aligned}
$$

where $K$ is the bedding value of the elastic foundation;

$$
\boldsymbol{E} \text { - is the flexural rigidity of the beam; }
$$

2) for the elastic half-space

with the elastic coefficient of $E_{0}$ and Poison's ratio of $v_{0}$

$$
\delta_{i, k}=\frac{1-v_{0}^{2}}{\pi E_{0} \tilde{n}} F_{i, k}+\frac{\ell^{3}}{3 E} w_{i, k},
$$

where the dimensionless function $F_{i, k}$ is defined by the following relations [7]

$$
\begin{aligned}
F_{i, i} & =2 \frac{c}{b}\left[\ln \frac{b}{c}+\frac{b}{c} \ln \left(\frac{c}{b}+\sqrt{\frac{c^{2}}{b^{2}}+1}\right)+\ln \left(1+\sqrt{\frac{c^{2}}{b^{2}}+1}\right)\right] \\
F_{i, k} & =\frac{1}{\left|x_{i}-x_{k}\right|}
\end{aligned}
$$

where $\mathrm{b}$ and $\mathrm{c}$ are the dimensions of the Zhem

ochkin's area on the beam (b is the beam width).

The dimensionless beam sags with pinching at the beam edge in the basic system of the mixed methods are to be determined from the formula [7] 


$$
\begin{aligned}
& w_{i, k}=\frac{x_{i}^{2}}{\ell^{2}}\left(3 \frac{x_{k}}{\ell}-\frac{x_{i}}{\ell}\right), \quad x_{k}>x_{i} ; \\
& w_{i, k}=\frac{x_{k}^{2}}{\ell^{2}}\left(3 \frac{x_{i}}{\ell}-\frac{x_{i}}{\ell}\right), \quad x_{k}<x_{i}
\end{aligned}
$$

The free terms of the system (1) depend on the external load and are to be determined with the use of the formulae (3). We will note that the last equation in (1) expresses the condition of absence of relative vertical motion in the intermediate pivot joint between neighbouring beams.

If the number of beams is designated as $N$, the total number of unknown forces in the Zhemochkin bonds, linear and angular motions of the introduced pinching on the beams and transverse forces in the intermediate pivot joints for computing this system of composite beams will be expressed by the formula:

$$
N(m+2)+N-1
$$

The structure of the system of resolving equations for the system of beams is presented in Figure 4. The blocks on the main diagonal are formed according to system (1), the supplementary blocks are zero ones in case of the Winkler foundation; in case of elastic halfspace, they characterise the mutual influence of the beams and are determined with the use of formulae (2).

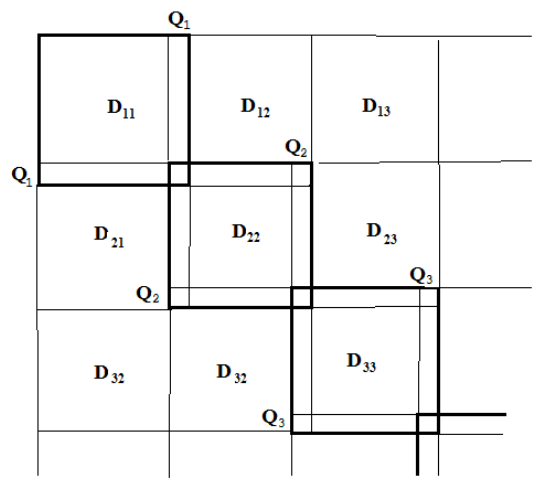

Figure 4. Structure of the system of resolving equations 
Taking into account the physical nonlinearity in the beam. Algorithm of nonlinear computation After determining the forces in the B.N.Zhemochkin's bonds at the contact of each beam with the elastic foundation by linear computation, the bending moment values in each section of each beam are determined by known structural mechanics methods [6]. From the calculated values of the moments, the tangential rigidity for each Zhemochkin's area on the beam is determined using the formula of the adopted "moment-curvature" dependence for the beam sections. In the work, it is adopted as hyperbolic tangent [9]. Therefore

$$
B_{i}^{(1)}=\frac{B_{0}}{\operatorname{Cosh}^{2}\left(\frac{B_{0}}{M \lim } \chi_{i}^{(0)}\right)},
$$

where $B_{0}$ - is the initial flexural rigidity of the Zhemochkin's area with the number $i$ according to elastic analysis (zero iteration);

$M \lim$ - is the ultimate moment perceived by the beam section. In this work, it is determined using the Beta program [10];

$\chi_{i}^{(0)}-$ is the curvature at the Zhemochkin's area with the number $i$ to be determined after the elastic analysis from the formula of finite differences [8].

$$
\chi_{i}^{(0)}=\frac{y_{i+1}^{(0)}-2 y_{i}^{(0)}+y_{i-1}{ }^{(0)}}{c^{2}},
$$

where $y_{i}^{(0)}$ - is the vertical motion at the centre of the Zhemochkin's area with the number $i$ according to the elastic analysis. It is determined according to the known forces in the Zhemochkin's bonds

$$
\begin{gathered}
y_{i}^{(0)}=\frac{X_{i}^{(0)}}{k}-\text { for an elastic Winkler's foundation; } \\
y_{i}{ }^{(0)}=\frac{1-v_{0}^{2}}{\pi E_{0} \Delta x} \sum_{n=1}^{m} \sum_{k=1}^{N} F_{i, n} X_{n}^{(0)}-\text { for the elastic half-space. }
\end{gathered}
$$

In the further computation, it is necessary to determine the coefficients of canonical equations $\delta_{i, k}{ }^{(1)}$ and $\Delta_{i, p}{ }^{(1)}$ as for the 
variable-rigidity beam. To do this, we use the Mohr's integral presentation [7] as a sum

$$
\delta_{i, k}^{(1)}=\sum_{n=1}^{m} \frac{M_{i}^{n} M_{k}{ }^{n}}{B_{n}^{(1)}} \Delta x
$$

The free terms $\Delta_{i, p}{ }^{(1)}$ of the system (1) are determined similarly. Multiplication of epures for a variable-rigidity beam is shown in Figure 5.
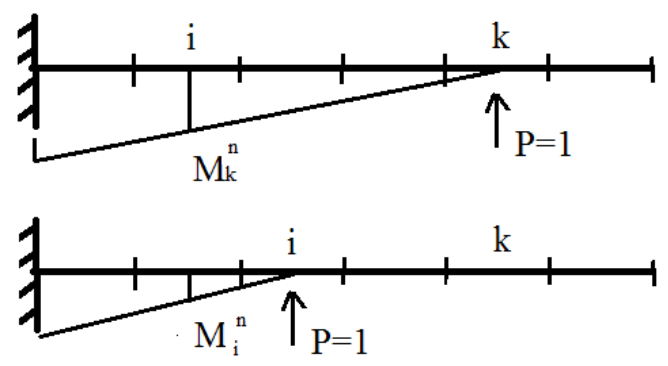

Figure 5. Multiplication of epures for a variable-rigidity beam

Based on the calculated $\delta_{i, k^{(1)}}{ }^{(1)}$ and $\Delta_{i, p}{ }^{(1)}$ values, the system (1) is solved again and the new $X_{i}^{(1)}$ values in the Zhemochkin's bonds. To determine the corrected rigidity values $B_{i}^{(2)}$, the calculations (5)-(8) are repeated at each Zhemochkin's area. Further, the $\delta_{i, k}$ and $\Delta_{i, p}{ }^{(2)}$ are determined again, the system (1) is solved, the $X_{i}^{(2)}$ are determined, etc. The iteration process is completed, when the difference

$$
\left|M_{i}^{(r)}-M_{i}^{(r-1)}\right| \leq \varepsilon
$$

where $\varepsilon-$ is the specified error value.

Numerical results Let us consider a system consisting of three pivotally-connected beams with equal length of $\ell=5 i$ and section of $1.2 \mathrm{~m} \mathrm{X} \mathrm{0,4} \mathrm{m} \mathrm{made} \mathrm{of} \mathrm{heavy} \mathrm{concrete} \mathrm{of} \mathrm{the} \mathrm{class} \mathrm{C20/25} \mathrm{on} \mathrm{an} \mathrm{elastic}$ Winkler foundation with the bedding value of $K=2000 \mathrm{kN} / \mathrm{m} 3$. 
The middle beam is loaded with uniformly distributed load of $q=120 \mathrm{kN} / \mathrm{m}$. When performing the computation, each beam was divided into 21 Zhemochkin's area.

Table 1 presents the numerical values for the contact stress, settlement, moment and rigidity at the centre of the middle beam for the first two iterations. The transverse forces in the two intermediate pivot joints are equal to $97.04 \mathrm{kN}$ after the last iteration.

Table 1

Results of the nonlinear computation

\begin{tabular}{|c|c|c|c|}
\hline Iteration number & $\begin{array}{c}\mathbf{0} \\
\text { (elastic analysis) }\end{array}$ & $\begin{array}{c}\mathbf{1} \\
\text { (first iteration) }\end{array}$ & $\begin{array}{c}\mathbf{2} \\
\text { (second iteration) }\end{array}$ \\
\hline Contact stresses, $\mathrm{kPa}$ & 82.57 & 82.41 & 82.41 \\
\hline Settlement, $\mathrm{mm}$ & 9.806 & 9.810 & 9.810 \\
\hline $\begin{array}{c}\text { Maximum bending moment in } \\
\text { the middle beam, } \mathrm{kN} \cdot \mathrm{m}\end{array}$ & 118.959 & 118.897 & 118.894 \\
\hline $\begin{array}{c}\text { Rigidity at the centre of the } \\
\text { middle beam, } \mathrm{kN} \cdot \mathrm{m} 2\end{array}$ & 185,920 & 182,070 & 181,171 \\
\hline
\end{tabular}

The analysis of numerical results of Table 1 confirms the known fact that the beam sags increase and the forces in the beams decrease when performing the computation of reinforce-concrete bending beams taking into account the physical nonlinearity. It should be noted that there are no bending moments in a single beam on a Winkler foundation under the action of uniformly distributed load. No such phenomenon is observed in the given example.

\section{CONCLUSION}

In this work, a simple technique for computation of pivotallyconnected reinforced-concrete foundation beams on an elastic foundation taking into account the physical nonlinearity of the beams is proposed. The technique is based on the mixed method of structural mechanics with the use of the Zhemochkin's method, the influence functions of which allow taking into account different models of an elastic foundation when simulating the latter. The physical nonlinearity 
of the material is taken into account by approximation of the "momentcurvature" dependence in a reinforced-concrete beam by the hyperbolic tangent function and further use of the variable (tangential) rigidity in the iteration algorithm of nonlinear computation and following analysis of its convergence.

A numerical example of the nonlinear computation is presented with the use of the Mathematica 10.4 computer package for a system of three pivotally-connected beams on an elastic Winkler foundation.

\section{REFERENCES}

1. Korenev B. G. Voprosy rascheta balok i plit na uprugom osnovanii [Questions of calculation of beams and plates on the elastic basis]. Moscow: Stroyizdat, 1954. 127 p. (rus)

2. Popov G. Ya. O raschete neogranichennoy sharnirno-razreznoy balochnoy plity, lezhashchey na uprugom poluprostranstve [On the calculation of an unlimited hinged-split beam plate lying on an elastic half-space]. Izv. Universities, Construction and Architecture, 1959. No.3. pp. 25-33. (rus)

3. Simvulidy I. A. Sostavnyye balki na uprugom osnovanii [Composite beam on elastic foundation]. Moscow: Higher School, 1961. 204 p. (rus)

4. Serebryanyy R. V. Raschet tonkikh sharnirno-soyedinennykh plit na uprugom osnovanii [Calculation of thin pivotally connected plates on elastic Foundation]. Moscow: Stroyizdat, 1962. 64 p. (rus)

5. Yuryev O. G. Proceedings HB, 1963. No.29. No. VII. pp. 44-55. (rus)

6. Rzhanitsin A. R. Stroitelnaya mekhanika [Construction mechanics]. Moscow: Higher School, 1991. 439 p. (rus)

7. Zhemochkin B. N. Prakticheskiye metody rascheta fundamentnykh balok i plit na uprugom osnovanii [Practical methods of calculation of the Foundation beams and plates on elastic Foundation ]. Moscow: Stroyizdat, 1962. 239 p. (rus)

8. Gorbunov-Posadov M. I. i dr. Raschet konstruktsiy na uprugom osnovanii [Calculation of structures on an elastic base ]. Moscow: Stroyizdat, 1984. 679 p. (rus) 
9. Kozunova O. V. Primeneniye MKR v nelineynykh raschetakh balok na odnorodnom uprugom sloye [Application of MD in nonlinear calculations of beams on a homogeneous elastic layer]. International collection of scientific articles "Resortocean Materials, Constructs, Budul Sporudi". Rivne, Ukraine. 2008. Issue.17. pp.373-381 (rus)

10. Leshkevich O. N. PK Raduga. Versiya 2. Rukovodstvo polzovatelya [PK Raduga. Version 2. User manual]. Novopolotsk, Publishing House PSU. 31 p. (rus)

Received: 18.11.2019 